\title{
The Motives behind Dividend Policy
}

\author{
Winston Pontoh ${ }^{1}$
}

\begin{abstract}
:
The puzzle for dividend policy in Indonesia is still remain since the firms have uncertain distribution for dividends to their shareholders. The objectives of this study are testing the free cash flow theory, life cycle theory, and catering theory with 139 firms as samples which is listed in Indonesia Stock Exchange for period of 2010 to 2015.

This study finds that, firms in Indonesia are not at mature level and there is an existence for free cash flow effect on dividend payers with lower debt only, while catering effect is generally exist for firms as dividend payers. Furthermore, since the firms as non dividend payers are on growth level then they are generally use their profit and capital gain includes debts in purposes of investment activities.
\end{abstract}

Key Words : dividend policy, free cash flow, life cycle, catering

JEL Classification : G11, G14, G19, G32, G35

\footnotetext{
${ }^{1}$ Faculty of Economic and Business, Sam Ratulangi University, Manado - Indonesia, +6285240839556,winstonpontoh@unsrat.ac.id
} 


\section{Introduction}

Dividend policy is remain a puzzle after years since sounded by Black (1996). According to Black (1996), understanding the motives by firms and shareholders are important to do in terms to view the issues behind dividend policy. Black (1996) clarifies that, it is difficult to determine whether shareholders are demanding dividends or not, but if the attention by shareholders are dividends then firms shall not eliminate dividends.

The puzzle seems occur for dividend policy in Indonesia, since the firms have paid fluctuate amount for yearly dividends and the others have not paid yearly dividends as informed by Budiarso and Pontoh (2016). The puzzle seems more complex while the firms in Indonesia have varies shareholders as informed by Saerang and Pontoh (2016) who classifying the ownership for firms in Indonesia into two groups, which are : state and/or institutional ownership and individual and/or public ownership. This study observed, debts are the factor which makes these firms are varies in distributing their dividends since most of firms have large debt.

Notice the works by Budiarso and Pontoh (2016) and Saerang and Pontoh (2016), then the study resolves the issues behind dividend policy in perspectives of three theories, which are free cash flow theory, life cycle theory, and catering theory. Free cash flow theory emphasizes that dividend policy arise because of conflict between shareholders and managers (Jensen, 1988; Kuan, Li, and Liu, 2012; Thalassinos and Liapis, 2014; Liapis et al., 2013). While life cycle theory emphasizes that firms are paying their dividends to shareholders because they are mature (Grullon, Michaely, and Swaminathan, 2002; DeAngelo, DeAngelo, and Stulz, 2006). Another opinion proposed by Baker and Wurgler (2004a, 2004b) is called catering theory, where this theory emphasizes that firms shall pay their dividends (cater) if only shareholders or investors overvalue their share price in market.

The study proceeds as follows, section 2 reviews the relevant literatures and then develops the hypothesis, section 3 explains the research method includes describing the samples and variables, section 4 presents the result and discuss the findings, and section 5 concludes the findings.

\section{Literature Review}

\subsection{Free cash flow theory}

Free cash flow theory is a theory which emphasizes that dividend policy arise by conflict of interests between shareholders and managers (Jensen, 1988; Kuan, Li, and Liu, 2012). According to Jensen (1988), Aivazian, Ge, and Qiu (2005), and Fairchild, Guney, and Thanatawee (2014), the symptom of conflict is started when firms have excess cash which evoke a collision about how to allocate the cash, whether need to distribute as dividends for shareholders or spend it for investments 
which at the end the return of these investments shall give benefit for managers. The conflict is exist while shareholders prevent the managers for overinvest and demand for dividends (Easterbrook, 1984; Jensen, 1986; Thalassinos et al., 2015a; 2015b).

Following Jensen (1986), Myers (2001) explains that, the free cash flow theory is a theory that applicable especially for profitable firms or mature firms in condition of overinvest, where debt can be used by shareholders as a tool for controlling and disciplining the managers. In similar, Thakor and Wilson (1995), Neale, Milsom, Hills, and Sharples (1998), Aivazian, Ge, and Qiu (2005), Brav, Graham, Harvey, and Michaely (2005), Fairchild, Guney, and Thanatawee (2014), and Saerang and Pontoh (2016) are also suggest to obtain the debt in term to control the expenditures for investments activities by managers and distribute the profit as dividends to shareholders.

\subsection{Life cycle theory}

The basic concept for life cycle theory is the firms normally paying their dividends to shareholders because they are on peak stage in their life cycle or maturity (Grullon, Michaely, and Swaminathan, 2002). Furthermore, Grullon, Michaely, and Swaminathan (2002) confirm that, at mature stage, most of the firms are characterized by large of free cash flow while their capital expenditures are shrinking, which is consistence with Garengo, Nudurupati, and Bititci (2007) who give description that, at stage of maturity, most of firms are usually have good governance and better performance.

The relationship with dividend policy, DeAngelo, DeAngelo, and Stulz (2006) confirming that, the mature firms are have high tendencies to distribute their earnings in form of dividends to their shareholders because they have better profitability with small investment opportunities. Moreover, DeAngelo, DeAngelo, and Stulz (2006) emphasize that, mature firms often increase their dividends for their shareholders because these firms are supported by abundant portion of retained earnings, which is consistent with the findings by Fairchild, Guney, and Thanatawee (2014), Budiarso and Pontoh (2016) and Saerang and Pontoh (2016) who confirm that, mature firms are normally increase their dividends because they are much larger, more profitable, have higher cash flows and have higher retained earnings ratios, although Fairchild, Guney, and Thanatawee (2014) also pointing, higher debt generally decreases dividend payments.

\subsection{Catering theory}

The other explanation about phenomenon behind dividend policy is catering policy which first time proposed by Baker and Wurgler (2004a, 2004b). According to Baker and Wurgler (2004a, 2004b), the basic concept for this theory is firms or managers shall pay their dividends (cater) if only shareholders or investors are put higher price on their shares in the market. Moreover, Baker and Wurgler (2004a) 
explain that, there are three main points for catering theory, which are : (1) psychological or institutional reasons; (2) uninformed investor; and (3) firms with rationally will cater for investor's demand, or in the other words, rational distribution of dividends.

Baker and Wurgler (2004a, 2004b) confirm that, the catering theory emphasizes that investor's psychological or sentiment will react under dividends announcement if they are uninformed, and this finding is consistent with Dreman and Lufkin (2000), Li and Zhao (2008), Polk and Sapienza (2009), Pontoh (2015) and Budiarso and Pontoh (2016). In addition, Li and Lie (2006) explain that, firms who not cater the shareholders or investors with dividends are generally penalized by decreasing share price in market.

\subsection{Hypothesis development}

\subsubsection{Debt assets ratio}

Notice the works by Jensen (1986), Thakor and Wilson (1995), Neale, Milsom, Hills, and Sharples (1998), Myers (2001), Aivazian, Ge, and Qiu (2005), Brav, Graham, Harvey, and Michaely (2005), Fairchild, Guney, and Thanatawee (2014), Thalassinos et al. (2012; 2015a, 2015b) and Saerang and Pontoh (2016) this study suspects, if shareholders are using debt as tool in term to control the investment activities by managers includes disciplining them then free cash flow theory is exist, where debt has positive significant effect to dividend policy.

$H a_{1}$ : Debt assets ratio has positive significant effect to dividend.

\subsubsection{Ratio of retained earnings to total assets}

Notice the works by Grullon, Michaely, and Swaminathan (2002), DeAngelo, DeAngelo, and Stulz (2006), Fairchild, Guney, and Thanatawee (2014), Budiarso and Pontoh (2016) and Saerang and Pontoh (2016) this study suspects, if the firms are on level of maturity then they have large retained earnings, which means they shall able to pay dividends to their shareholders make retained earnings has positive significant effect to dividend policy.

$\mathrm{Ha}_{2}$ : Retained earnings to total assets ratio has positive significant effect to dividend.

\subsubsection{Share price}

Notice the works by Baker and Wurgler (2004a, 2004b), Dreman and Lufkin (2000), $\mathrm{Li}$ and Zhao (2008), Polk and Sapienza (2009), Pontoh (2015) and Budiarso and Pontoh (2016) this study suspects, if share price is triggering the firms to pay their 
dividends then catering theory is exist, where share price has positive significant effect to dividend policy.

$\mathrm{Ha}_{3}$ : Share price has positive significant effect to dividend.

\subsubsection{Return on assets}

Free cash flow effect generally exist for mature firms or profitable firms (Myers, 2001) as confirmed by DeAngelo, DeAngelo, and Stulz (2006), Jordan, Liu, and Wu (2014), Budiarso and Pontoh (2016) and Saerang and Pontoh (2016), makes this study suspects that, if profit is the most determinant factor for distribution of dividends then both for free cash flow and life cycle theories, profit has positive significant effect to dividend policy.

$\mathrm{Ha}_{4}$ : Return on assets has positive significant effect to dividend.

\subsubsection{Tangibility}

Notice the works by Jensen (1986), Thakor and Wilson (1995), Neale, Milsom, Hills, and Sharples (1998), Myers (2001), Aivazian, Ge, and Qiu (2005), Brav, Graham, Harvey, and Michaely (2005), Fairchild, Guney, and Thanatawee (2014), and Saerang and Pontoh (2016) then in condition where the free cash flow and life cycle theories can be applied, firms shall use debt in order for financing additional fixed assets. The profit gained by those assets then can be used for paying debt and its interest and also distributes as dividends.

$\mathrm{Ha}_{5}$ : Tangibility has positive significant effect to dividend.

\section{Research Methodology}

\subsection{Sample}

This study uses 139 firms as samples which is listed in Indonesia Stock Exchange (www.idx.co.id) for period of 2010 to 2015 as defines in Table 1. As the samples, the firms should published their audited financial report and have the information needed by this study in observed period. This study excluding the finance sector and property, real estate, and building construction sector since they have different financial report structure.

Table 1. Samples

\begin{tabular}{lll}
\hline Sectors & Samples & Observed \\
\hline Agriculture & 9 & 54 \\
Mining & 14 & 84 \\
Basic Industry \& Chemicals & 31 & 186 \\
Miscellaneous Industry & 18 & 108
\end{tabular}


Consumer Goods Industry $16 \quad 96$

Infrastructure, Utilities, and Transportation $\quad 12 \quad 72$

Trade, Service, Investment

39234

Total

139
834

\subsection{Variable definitions}

Table 2 defines the dependent variable and independent variables for this study. The dependent variable for this study is dividend policy measured by dummy with codes as follow : 1 for firms who pay dividend at least more or equal than average Rp. 1 in observed period (called as dividend payers) and 0 for firms who not pay dividend in observed period (called as non dividend payers). Furthermore, this study is following the cut off by Weijermars (2012) and Bonaimé, Öztekin and Warr (2014) to classify the debt ratio based on its average for each firms into higher or lower debt, where firms who have over $50 \%$ debt ratio can be called firms with higher debt or vice versa. In addition, this study is normalized all independent variables by natural logarithms since they have different unit measurements.

Table 2. Variable Definitions

\begin{tabular}{|c|c|c|}
\hline Variables & & Measurement \\
\hline Dividend (DIV) & & Dummy \\
\hline Debt assets ratio (DAR) & & Ratio of total debt to total assets \\
\hline $\begin{array}{l}\text { Retained earnings } \\
\text { (RETA) }\end{array}$ & ratio & Ratio of retained earnings to total assets \\
\hline Price (PRICE) & & $\begin{array}{l}\text { Closing share price at the end of year after corporate } \\
\text { action }\end{array}$ \\
\hline Return on assets (ROA) & & Ratio of net profit to total assets \\
\hline Tangibility (TANG) & & Ratio of total fixed assets to total assets \\
\hline
\end{tabular}

\subsection{Regression model}

The hypotheses testing for this study is conducting logistic regression analysis at significance $5 \%$ with equation model as follows :

$\mathrm{DIV}_{\text {dummy }}=\alpha+\beta_{1} \mathrm{DAR}+\beta_{2}$ RETA $+\beta_{3}$ PRICE $+\beta_{4} \mathrm{ROA}+\beta_{5} \mathrm{TANG}+\varepsilon$

This study also uses the chi square value in term to determine whether the model is fit or model is not fit at significance $5 \%$.

\section{Results and Discussion}

\subsection{Descriptive Statistics}

Table 3 presents the descriptive statistics for the samples of this study. In category of firms with lower debt, the dividend payers have higher ratio of total debt to total assets, share prices, and ratio of net profit to total assets rather than non dividend payers except for ratio of total fixed assets to total assets, which giving presumptions 
the possibilities for existence of free cash flow effect and catering effect. Moreover, the higher ratio of retained earnings to total assets by dividend payers assumes that, these firms are more mature rather than firms as non dividend payers.

The category of firms with higher debt shows that, the dividend payers have higher share prices and ratio of net profit to total assets rather than non dividend payers which giving presumptions the possibilities for existence of catering effect on these firms. Also, the higher ratio of retained earnings to total assets by firms as dividend payers indicates these firms are more mature than firms as non dividend payers.

The firms as non dividend payers have higher ratio of total debt to total assets and ratio of total fixed assets to total assets than firms as dividend payers which giving presumptions these firms are obtaining debts in term for investment activities or otherwise, the existence of free cash flow effect.

This study also reports that, the ratio of total fixed assets to total assets for non dividend payers both with lower or higher debt are similar which means these firms are emphasize on investment activities includes confirms the results for debt, share prices, and profitability.

Table 3. Descriptive Statistics

\begin{tabular}{llll}
\hline & Minimum & Maximum & Mean \\
\hline Dividend payers with lower debt $(N=330)$ & & & \\
DAR & 0.04 & 0.98 & 0.33 \\
RETA & -2.22 & 1.33 & 0.41 \\
PRICE & 0.00 & 132500.00 & 6624.92 \\
ROA & -0.14 & 0.75 & 0.12 \\
TANG & 0.02 & 0.91 & 0.28 \\
& & & \\
Non dividend payers with lower debt $(N=144)$ & & & \\
DAR & 0.00 & 0.82 & 0.30 \\
RETA & -3.31 & 0.88 & -0.12 \\
PRICE & 50.00 & 18050.00 & 1411.51 \\
ROA & -0.62 & 0.37 & 0.01 \\
TANG & 0.00 & 0.96 & 0.43 \\
& & & \\
Dividend payers with higher debt $(N=22)$ & & & \\
DAR & 0.35 & 2.12 & 0.67 \\
RETA & -0.17 & 1.10 & 0.17 \\
PRICE & 63.00 & 37000.00 & 2827.46 \\
ROA & -0.16 & 0.72 & 0.05 \\
TANG & 0.00 & 0.99 & 0.34 \\
Non dividend payers with higher debt $(N=138)$ & & & \\
DAR & & & \\
RETA & & & \\
PRICE & -26.74 & 1.80 & -0.76 \\
& 35.00 & 2000.00 & 412.66
\end{tabular}




$\begin{array}{llll}\text { ROA } & -1.28 & 3.47 & 0.01\end{array}$

$\begin{array}{llll}\text { TANG } & 0.00 & 0.88 & 0.38\end{array}$

\subsection{Firms in general condition}

The model for general condition means this study is running the regression without controlling the debt ratio. Table 4 shows that all chi square are insignificant at 5\% which means all the models are fit for both of dividend payers and non dividend payers. In this condition, debt assets ratio $\left(\mathrm{Ha}_{1}\right)$, share price $\left(\mathrm{Ha}_{3}\right)$, and return on assets $\left(\mathrm{Ha}_{4}\right)$ have positive significant effect to dividend policy, which means free cash flow effect and catering effect are exists on firms as dividend payers. Otherwise, on firms as non dividend payers these variables have negative significant effect to dividend policy. The earnings to total assets ratio $\left(\mathrm{Ha}_{2}\right)$ and tangibility $\left(\mathrm{Ha}_{5}\right)$ are insignificant to dividend policy, which means that, in general condition dividend payers and non dividend payers are not firms at mature level.

\section{3. $\quad$ Firms with lower debt}

Table 4 shows that all chi square are insignificant at 5\% which means all the models are fit for both of dividend payers and non dividend payers. Table 4 also shows that, for dividend payers, debt assets ratio $\left(\mathrm{Ha}_{1}\right)$, share price $\left(\mathrm{Ha}_{3}\right)$, and return on assets $\left(\mathrm{Ha}_{4}\right)$ have positive significant effect to dividend policy as predicted by hypotheses of this study, while for non dividend payers, these variables have negative significant effect to dividend policy. The earnings to total assets ratio $\left(\mathrm{Ha}_{2}\right)$ and tangibility $\left(\mathrm{Ha}_{5}\right)$ are insignificant to dividend policy, which is giving an implication that, dividend payers and non dividend payers are not firms at mature level in context of life cycle theory. These results are confirming the results for firms in general condition.

Consistent with Jensen (1986), Thakor and Wilson (1995), Neale, Milsom, Hills, and Sharples (1998), Myers (2001), Aivazian, Ge, and Qiu (2005), Brav, Graham, Harvey, and Michaely (2005), Fairchild, Guney, and Thanatawee (2014), and Saerang and Pontoh (2016), the result shows that, debts are playing its role in term to control the activities by managers, which indicates the existence of free cash flow effect for firms as dividend payers. Otherwise, the existence of debts for non dividend payers are not caused by free cash flow effect because the result shows that, increasing in debts makes these firms are decreasing their dividends to their shareholders, which indicates debts shall create inability to pay dividends since these firms are bearing the interest expenses which reducing their profit.

Consistent with Baker and Wurgler (2004a, 2004b), Dreman and Lufkin (2000), Li and Zhao (2008), Polk and Sapienza (2009), Pontoh (2015) and Budiarso and Pontoh (2016), the positive effect by share price shows that the catering effect is exist for firms as dividend payers but not for firms as non dividend payers. The negative effect by share prices for firms as non dividend payers indicates these firms are 
retained their capital gain for other intentions which are most possibly for financing their projects.

The positive effect by return on assets for firms as dividend payers is consistent with DeAngelo, DeAngelo, and Stulz (2006), Jordan, Liu, and Wu (2014), Budiarso and Pontoh (2016) and Saerang and Pontoh (2016) which implies that, profitability is a factor to support their decision for debt policy in term to avoid the free cash flow effect includes triggering the sentiment from investors through a good news about their profit which shall create the catering effect. Whereas the negative effect by return on assets for firms as non dividend payers is supporting the indications on results of debt policy and share price, where these firms tend to keep some portion of earnings with purposes for investments.

Table 4. Logistic Regression for Dividend Policy

\begin{tabular}{|c|c|c|}
\hline \multirow[b]{2}{*}{ Dependent Variable } & Dividend Payers & Non Dividend Payers \\
\hline & Dividend (dummy) & Dividend (dummy) \\
\hline \multicolumn{3}{|c|}{ Firms in general condition $(N=834)$} \\
\hline Constant & -2.983 & 2.983 \\
\hline DAR & $0.457 *$ & $-0.457 *$ \\
\hline RETA & 0.037 & -0.037 \\
\hline PRICE & $0.847 *$ & $-0.847 *$ \\
\hline $\mathrm{ROA}$ & $0.404 *$ & $-0.404 *$ \\
\hline TANG & 0.010 & -0.010 \\
\hline Chi-square & 0.146 (fit model) & 0.202 (fit model) \\
\hline \multicolumn{3}{|c|}{ Firms with lower debt $(N=474)$} \\
\hline Constant & 0.209 & -0.209 \\
\hline DAR & $1.008^{*}$ & $-1.008 *$ \\
\hline RETA & 0.229 & -0.229 \\
\hline PRICE & $0.652 *$ & $-0.652 *$ \\
\hline $\mathrm{ROA}$ & $0.772 *$ & $-0.772 *$ \\
\hline TANG & -0.124 & 0.124 \\
\hline Chi-square : & 0.073 (fit model) & 0.118 (fit model) \\
\hline \multicolumn{3}{|c|}{ Firms with higher debt $(N=360)$} \\
\hline Constant & -4.912 & 4.912 \\
\hline DAR & -0.504 & 0.504 \\
\hline RETA & 0.133 & -0.133 \\
\hline PRICE & $1.016^{*}$ & $-1.016^{*}$ \\
\hline ROA & $0.251 *$ & $-0.251 *$ \\
\hline TANG & -0.060 & 0.060 \\
\hline Chi-square significance: & 0.271 (fit model) & 0.271 (fit model) \\
\hline
\end{tabular}

\footnotetext{
*significant at $5 \%$
} 


\subsection{Firms with higher debt}

Table 4 shows that all chi square are insignificant at 5\% which means all the models are fit for both of dividend payers and non dividend payers. Table 4 also shows that, for dividend payers, share price $\left(\mathrm{Ha}_{3}\right)$ and return on assets $\left(\mathrm{Ha}_{4}\right)$ have positive significant effect to dividend policy as predicted by hypotheses of this study, while for non dividend payers, these variables have negative significant effect to dividend policy. The debt assets ratio $\left(\mathrm{Ha}_{1}\right)$, earnings to total assets ratio $\left(\mathrm{Ha}_{2}\right)$ and tangibility $\left(\mathrm{Ha}_{5}\right)$ are insignificant to dividend policy, which is giving an implication that, dividend payers and non dividend payers are not in conflict of interests between shareholders and managers in context of free cash flow theory and also not firms at mature level in context of life cycle theory.

Similar to firms as dividend payers with lower debt, the positive effect by share price shows that the catering effect is exist for firms as dividend payers with higher debt which is consistent with Baker and Wurgler (2004a, 2004b), Dreman and Lufkin (2000), Li and Zhao (2008), Polk and Sapienza (2009), Pontoh (2015) and Budiarso and Pontoh (2016). Also, similar to firms as non dividend payers with lower debt, the negative effect by share prices for non dividend payers with higher debt indicates these firms have same intentions especially for investment activities.

Similar to firms as dividend payers with lower debt, the positive effect by return on assets for firms as dividend payers with higher debt is consistent with DeAngelo, DeAngelo, and Stulz (2006), Jordan, Liu, and Wu (2014), Budiarso and Pontoh (2016) and Saerang and Pontoh (2016) which implies that, profitability also is a factor to trigger the sentiment from investors through a good news which shall create the catering effect. This result also confirms the insignificant effect by debt ratio which means, profitability is not a factor to support their debt policy. Whereas the negative effect by return on assets implies same purposes between firms as non dividend payers with lower and higher debt.

\section{Conclusions}

The motives by firms behind dividend policy can be seen in perspectives of free cash flow theory, life cycle theory, and catering theory. This study extents the testing for these theories in term to reveal the motives behind dividend policy by conducting logistic regression analysis with controlling the variable for debt and uses 139 firms as samples which is listed in Indonesia Stock Exchange for period of 2010 to 2015.

This study reports that, both of dividend payers and non dividend payers with lower debt are not firms at mature level. Supported by profitability, the free cash flow effect and catering effect are exists for dividend payers with lower debt. While firms as non dividend payers with lower debt, in purposes for investments then these firms are not paying their dividends because they are bearing the debt interest expenses and retained their capital gain. 
Furthermore, this study reports that, both of dividend payers and non dividend payers with higher debt are also not at mature level and also do not have conflict of interests between shareholders and managers. Similar to firms as dividend payers with lower debt, the catering effect is exist for firms as dividend payers with higher debt, while there is similar behavior in treating capital gain between non dividend payers with lower debt and non dividend payers with higher debt.

\section{References}

Aivazian, V.A., Ge, Y., \& Qiu, J. 2005. The impact of leverage on firm investment : Canadian evidence. Journal of Corporate Finance, 11, 277-291.

Baker, M., \& Wurgler, J. 2004a. A Catering Theory of Dividends. The Journal of Finance, 59(30), 1125-1165.

Baker, M., \& Wurgler, J. 2004b. Appearing and Disappearing Dividends : The Link to Catering Incentives. Journal of Financial Economics, 73(2), 271-288.

Black, F. 1996. The Dividend Puzzle. The Journal of Portfolio Management, Special Issue, 8-12.

Bonaimé, A.A., Öztekin, Ö., \& Warr, R.S. 2014. Capital Structure, Equity Mispricing, and Stock Repurchases. Journal of Corporate Finance, 26, 182-200.

Brav, A., Graham, J.R., Harvey, C.R., \& Michaely, R. 2005. Payout policy in the $21^{\text {st }}$ century. Journal of Financial Economics 77, 483-527.

Budiarso, N.S., \& Pontoh, W. 2016. Firm's Dividend Decision in Indonesia : Cater or Mature ? Journal of Life Economics, 3(3), 53-66.

DeAngelo, H., DeAngelo, L., \& Stulz, R.M. 2006. Dividend Policy and the Earned/Contributed Capital Mix : A Test of the Life-Cycle Theory. Journal of Financial Economics, 81(2), 227-254.

Dreman, D.N., \& Lufkin, E.A. 2000. Investor Overreaction: Evidence That Its Basis Is Psychological. The Journal of Psychology and Financial Markets, 1(1), 61-75.

Easterbrook, F.H. 1984. Two agency-cost explanations of dividends. The American Economic Review, 74(4), 650-659.

Fairchild, R., Guney, Y., \& Thanatawee, Y. 2014. Corporate dividend policy in Thailand : Theory and Evidence. International Review of Financial Analysis, 31, 129-151.

Garengo, P., Nudurupati, S., \& Bititci, U. 2007. Understanding the Relationship between PMS and MIS in SMEs : An Organizational Life Cycle Perspective. Computers in Industry, 58, 677-686.

Grullon, G., Michaely, R., \& Swaminathan, B. 2002. Are Dividend Changes a Sign of Firm Maturity? The Journal of Business, 75(3), 387-424.

Jensen, M.C. 1986. Agency costs of free cash flow, corporate finance, and takeover. American Economic Review, 76(2), 323-329.

Jensen, M.C. 1988. Takeovers : Their causes and consequences. The Journal of Economic Perspectives, 2(1), 21-48.

Jordan, B.D., Liu, M.H., dan Wu, Q. 2014. Corporate Payout Policy in Dual-Class Firms. Journal of Corporate Finance, 26, 1-19.

Kuan, T.H., Li, C.S., \& Liu, C.C. 2012. Corporate governance and cash holdings : A quantile regression approach. International Review of Economics and Finance, 24, 303-314.

Liapis, K., Rovolis, A., Galanos, C. and Thalassinos, I.E. 2013. The Clusters of Economic Similarities between EU Countries: A View Under Recent Financial and Debt Crisis. European Research Studies Journal, 16(1), 41-66. 
Li, K., \& Zhao, X. 2008. Asymmetric Information and Dividend Policy. Financial Management, 37(4), 673-694.

Li, W., \& Lie, E. 2006. Dividend Changes and Catering Incentives. Journal of Financial Economics, 80(2), 293-308.

Myers, S.C. 2001. Capital structure. The Journal of Economic Perspectives, 15(2), 81-102.

Neale, B., Milsom, T., Hills, C., \& Sharples, J. 1998. The hostile takeover process : a case study of Granada versus Forte. European Management Journal, 16(2), 230-241.

Polk, C., \& Sapienza, P. 2009. The Stock Market and Corporate Investment: A Test of Catering Theory. The Review of Financial Studies, 22(1), 187-217.

Pontoh, W. 2015. Signaling, Bird in the Hand, and Catering Effect in Indonesia. Journal of Life Economics, 2(3), 1-24.

Saerang, D.P.E., \& Pontoh, W. 2016. The Role of Ownership on Behavior of Dividend Payers. Journal of Life Economics, 3(4), 59-68.

Thakor, A.V., \& Wilson, P.F. 1995. Capital requirements, loan renegotiation and the borrower's choice of financing source. Journal of Banking and Finance, 19, 693 711.

Thalassinos, I.E., Ugurlu, E. and Muratoglu, Y. 2012. Income Inequality and Inflation in the EU. European Research Studies Journal, 15(1), 127-140.

Thalassinos, I.E. and Liapis K. 2014. Segmental financial reporting and the internationalization of the banking sector. Chapter book in, Risk Management: Strategies for Economic Development and Challenges in the Financial System,(eds), D. Milos Sprcic, Nova Publishers, 221-255, ISBN: 978-163321539-9; 978163321496-5.

Thalassinos, I.E., Ugurlu, E. and Muratoglu, Y. 2015a. Comparison of Forecasting Volatility in the Czech Republic Stock Market. Applied Economics and Finance, 2(1), 11-18.

Thalassinos, I.E., Th. Stamatopoulos, D.T. and Thalassinos, E.P. 2015b. The European Sovereign Debt Crisis and the Role of Credit Swaps. Chapter book in The WSPC Handbook of Futures Markets (eds) W. T. Ziemba and A.G. Malliaris, in memory of Late Milton Miller (Nobel 1990) World Scientific Handbook in Financial Economic Series Vol. 5, Chapter 20, pp. 605-639, ISBN: 978-981-4566-91-9, (doi: 10.1142/9789814566926_0020).

Weijermars, R. 2012. Regulatory Reform Options to Revitalize the US Natural Gas Value Chain. Utilities Policy, 21, 50-58. 